\title{
PerCursos
}

\section{Do encobrimento da memória e do outro: uma analítica acerca dos relatos da colonização}

\begin{abstract}
Resumo
O surgimento da América é marcado por controvérsias e pelo encobrimento da memória e do outro (nativos americanos). Nesta perspectiva, o presente artigo busca traçar uma analítica acerca dos relatos da colonização, a partir dos quais, cria-se a figura do índio e suas associações. Para isso, o texto foi dividido em cinco eixos. Primeiramente, destaca-se o mito salvacionista do bom selvagem e a narrativa inicial da colonização. Após, evidencia-se a descaraterização do nativo 'ameríndio' de sua humanidade a fim de justificar sua exploração frente ao Novo Mundo, fato relacionado ao mito da modernidade e ao encobrimento da multiplicidade, que compõem o terceiro ponto de abordagem. No quarto ponto destaca-se a estratégica de dominação presente na nominação "índio" adotada pelos europeus para se referir aos nativos. No quinto ponto destacado ressalta-se o mito do encontro entre raças que mascara a violência e as estratégias de dominação do território. Por fim, encerra-se o texto, realizando um mergulho, submersão e emersão dos temas e pontos abordados. Conclui-se que a história dos povos americanos e a historiografia da colonização precisam ser revisitadas de forma a potencializar a percepção da outra face da chegada dos europeus e do encobrimento e desvalorização da memória dos povos originários da América.
\end{abstract}

Palavras-chave: Povos nativo americanos. Colonialidade. Eurocentrismo.

\section{Tascieli Feltrin}

Doutoranda e Mestra em Educação pela Universidade Federal de Santa Maria -UFSM. Professora da Rede Municipal de Ensino de Santa Maria. Brasil

tascifeltrin@gmail.com

\section{Natália Lampert Batista}

Mestra, Doutora e Pós-doutora em Geografia pela Universidade Federal de Santa Maria - UFSM.

Professora da Universidade

Federal de Santa Maria - UFSM. Brasil

natalia.batista@ufsm.br

\section{Guilherme Carlos Corrêa}

Doutor em Ciências Sociais-

Política pela Pontifícia

Universidade Católica de São

Paulo - PUC SP e Pós-doutor em

Educação pela Pontifícia

Universidade Católica do Rio Grande do Sul - PUCRS. Professor da Universidade Federal de Santa Maria - UFSM.

Brasil

gcarloscorrea@gmail.com

\section{Para citar este artigo:}

FELTRIN, Tascieli; BATISTA, Natália Lampert; CORRÊA, Guilherme Carlos. Do encobrimento da memória e do outro: uma analítica acerca dos relatos da colonização. PerCursos, Florianópolis, v. 22, n.48, p. 10 - 36, jan./abr. 2021.

\section{DOI: $10.5965 / 1984724622482021010$}

http://dx.doi.org/10.5965/1984724622482021010 


\title{
The covering of memory and the other: an analytical about colonization reports
}

\begin{abstract}
America's emergence is characterized by controversy and the concealment of memory and the other (Native Americans). Under this perspective, this study seeks to analyze the accounts of colonization from which the Indian figure and its associations are created. To this end, we divided the text into five axes. First, the salvationist myth of the good savage and the early colonization narrative stand out. Then, there is evidence of the native 'Amerindian' decharacterization from its humanity to justify its exploitation before the New World, a fact related to the myth of modernity and the concealment of multiplicity, which make up the third approach point. The fourth point highlights the domination strategy underlying the name "Indian" adopted by the Europeans to refer to the natives. The fifth point highlights the myth of the encounter between races that masks violence and territorial domination strategies. Finally, the text concludes, performing a dive, submersion, and emersion of the addressed themes and points. We conclude that the American peoples' history and the colonization historiography need to be revisited to enhance the perception of the other side of the Europeans' arrival and the concealment and devaluation of the native peoples' memory in America..
\end{abstract}

Keywords: Native American Peoples. Coloniality. Eurocentrism. 
A América é o único continente do qual sabemos a data precisa do começo, é o único formado por participação universal. Nasceu para ser outra coisa. (ARCINIEGAS, 1990, p. 62)

\section{Introdução}

O presente artigo busca traçar uma analítica acerca dos relatos da colonização, a partir dos quais, cria-se a figura do índio e suas associações. Os primeiros contatos entre colonizadores e povos nativos foram os substratos sobre os quais um vasto imaginário permeado por medos, preconceitos e interesses foi construído.

Os relatos da colonização, em especial, permitem perceber, com clareza, o delineamento da estratégia de desumanização dos nativos da qual decorrem a justificação do uso da violência, a criação de mitos que relacionam os modos de vida indígenas aos conceitos de pecado, a entidades malignas do catolicismo. Tais registros literários ou relatos históricos se utilizam de uma descrição exagerada das riquezas minerais e da flora, alicerçando na elite europeia um desejo de agir sobre o território e seus habitantes.

A literatura quinhentista, religiosa e eurocentrada tece linhas e cria paisagens no novo território: a descrição dos nativos, tornando difícil a intenção de conhecê-la sem aderir em alguns momentos ao fascínio de suas histórias. Para desviar às armadilhas de tornar esta escrita mais um mecanismo de reforço da colonialidade, buscamos amparo nas leituras de Quijano, Dussel, Foucault, Clastres, Maestri e Segatto.

Neste estudo, adota-se a nomenclatura nativo-americanos para fins de referência aos povos originários do continente americano em detrimento das expressões índios ou ameríndios, primeiramente porque a nomenclatura 'índio', como se verá no decorrer deste artigo, não se aplica a boa parte da população nativa americana; também opta-se pelo termo mais abrangente 'americano' devido ao fato de que os processos aqui elencados compõem a história de um território ainda não compartimentado em países, continentes, ou seja, referem-se a um período anterior à criação do Brasil e da América. Busca-se, a priori, reconhecer os nativos como seres possuidores de saberes, autores de estratégias educacionais provenientes de um outro modo de vida, alheio às estruturas 
capitalista, mercantilista e do conceito de modernidade, tendo, em vista disso, diminuída sua organização educacional, cultural e filosófica junto ao estilo de vida nativo diante da expansão do colonialismo. A tradição oral muito eficiente antes da chegada do europeu perdeu muito de seu espaço de produção de registros indeléveis, e a cultura estrangeira utilizando-se de mecanismos como a escolarização e a catequização tratou logo de se fixar com o uso da força do encobrimento. Por essa razão, o que se utiliza como substrato a este estudo são obras históricas produzidas dentro do processo de colonização a fim de ilustrar o ‘novo mundo’ aos europeus.

\section{O mito salvacionista do bom selvagem}

A emergência dos europeus no território americano deu-se em um intricado período de divergências (ciência/religião), pressões entre católicos e protestantes e por disputas políticas engendradas entre nações concorrentes. Essa imbricada tessitura de elementos impunha as condições do pensamento europeu que, a fim de dar coerência interna ao sistema de ideias colonialista, buscou afirmar sua soberania sobre o território americano e seus habitantes.

Em uma arrojada tentativa de harmonizar as incongruências internas do continente europeu, buscou-se operar, no discurso, em um primeiro momento, com o aparecimento de um 'novo mundo', com um imenso território, recursos naturais e humanos a serem explorados, sem 'leis', impostos ou classes sociais. Os relatos do 'descobrimento' davam conta de um paraíso no qual a pobreza e a fome geradas pelas inúmeras guerras internas e externas contra os Califados Muçulmanos estariam no passado. Voltavam-se ao convencimento de Clérigos e Reis da relevância das expedições empreendidas para além-mar. Pero Vaz de Caminha, escrivão da armada naval de Pedro Alvarez Cabral, inaugura este estilo de literatura com a escrita da Carta a El-Rei Dom Manuel I (15001), tida como o primeiro documento da colonização (portuguesa), no qual se desenha um território e personagens de acordo com os interesses envolvidos.

\footnotetext{
${ }^{1}$ Escrita na região onde se encontra Porto Seguro, entre os dias 26 de abril e 02 de maio de 1500.
} 
Eram pardos, todos nus, sem coisa alguma que lhes cobrisse suas vergonhas. Nas mãos traziam arcos com suas setas. Vinham todos rijos sobre o batel; e Nicolau Coelho lhes fez sinal que pousassem os arcos. $\mathrm{E}$ eles os pousaram. [...] a feição deles é serem pardos, maneira de avermelhados, de bons rostos e bons narizes, bem-feitos. Andam nus, sem nenhuma cobertura. Nem estimam de cobrir ou de mostrar suas vergonhas; e nisso têm tanta inocência como em mostrar o rosto. (CAMINHA, 1500)

A descrição dos nativos dava conta de uma chegada ao território sem conflitos ou resistências, em que os estrangeiros não foram mortos ou hostilizados, mas, sim, alvos da curiosidade e de certo acolhimento por parte dos nativos. Estes são descritos como inocentes, dóceis e pacíficos: o bom selvagem²! A carta era um convite à exploração, que iria viabilizar o envio de centenas de outros exploradores, angariar enormes investimentos e colocar o território e seus habitantes em um alvo.

Como linhas mestras, recorreram a artimanhas que visavam à mobilização de recursos financeiros: aos reis, insuflavam desejos por riqueza e glória: “um deles pôs olho no colar do Capitão, e começou de acenar com a mão para a terra e depois para o colar, como que nos dizendo que ali havia ouro. Também olhou para um castiçal de prata e assim mesmo acenava para a terra e novamente para o castiçal como se lá também houvesse prata" (CAMINHA, 1500); aos católicos, a possibilidade unificadora de uma nova cruzada; aos protestantes, a oportunidade de expansão e poder: "Enquanto estivemos à missa e à pregação, seria na praia outra tanta gente, pouco mais ou menos como a de ontem, com seus arcos e setas, a qual andava folgando. E olhando-nos, sentaram-se" (CAMINHA, 1500).

O confronto entre a visão do bom selvagem, disposto à conversão e possuidor de muitas riquezas, construída pelos primeiros navegadores e as condições de vida e de enfrentamento dos nativos exerce papel singular na escolha das estratégias que irão de fato dar a posse do território aos europeus. Mata-se o bom selvagem da literatura e, em seu lugar, surge a mais desumana criatura guerreira e antropófaga.

\footnotetext{
${ }^{2}$ A descrição de Caminha será base para o desenvolvimento do mito do bom selvagem defendido por JeanJacques Rousseau, em Do contrato Social: princípios do direito político, publicada em 1762, na França.
} 


\section{A descaracterização do nativo ‘ameríndio’ de sua humanidade}

Em um momento imediatamente posterior é a descaracterização do nativo de sua humanidade a ideia-força dos processos de colonização. No discurso produzido pelo europeu para seus pares sobre os nativos, tem-se um ataque às várias frentes que compunham o modo de vida nativo ${ }^{3}$, tais como: as práticas de guerra4 (canibalismo/ mutilação), as vestimentas (ou a falta delas 5 ), a organização dos relacionamentos matrimoniais e sexuais (inexistentes ou poligâmicos ${ }^{6}$ ), práticas culturais (nomadismo), religiosidade7 (ausente ou politeísta), relação com a natureza (cooperação e reverência), entre outros.

A estratégia utilizada fundamentou-se na associação da figura do nativo aos estereótipos primitivo, selvagem, degenerado e preguiçoso, todos investidos na categoria 'índio'. Opera-se com a criação de uma imagem de bestial, animalesco e sem cultura que justifique a ação violenta do colonizador sobre os ameríndios a fim de 'corrigir Ihes' e torná-los à sua imagem e semelhança. Para ilustrar essa estratégia, a seguir, trazem-se algumas obras que compõem os relatos de viajantes sobre o território e seus habitantes. Notadamente, nesse momento, instaura-se um projeto de aculturação, responsável por ir desconstruindo as tradições educacionais e culturais já estabelecidas

\footnotetext{
3 Importante destacar que as práticas descritas não eram unânimes, ou seja, não compunham um padrão de vida dos nativos, e a generalização produzida sobre a diversidade de culturas aqui é entendida como uma das formas de violência utilizada contra estes, a qual consiste em desconsiderar a individualidade dos sujeitos e dos povos, realizando um julgamento e uma classificação a partir do olhar do europeu.

4 "Esses americanos são tão ferozes e encarniçados em suas guerras que, enquanto podem mover braços e pernas, combatem sem recuar nem voltar as costas. Finalmente, quando chegam ao alcance das mãos, alcançaram as clavas, descarregando-se com tal violência que, quando acertavam na cabeça do inimigo, $o$ derrubavam morto como entre nós os magarefes abatem os bois" (LÉRY, 1980, p. 179).

5 "Estes índios andam nus sem cobertura alguma, assim machos como fêmeas; não cobrem parte nenhuma de seu corpo, e trazem descoberto quanto a natureza lhes deu" (GÂNDAVO, 1980, p. 13).

"Todos pardos, todos nus, sem nenhuma cousa que cobrisse suas vergonhas [...] e Nicolau Coelho lhes fez sinal que pousassem os arcos. E eles os depuseram. Mas não pôde deles haver fala nem entendimento que aproveitasse, por o mar quebrar na costa" (CAMINHA, 1500).

6 "Tem três, quatro mulheres, a primeira tem em mais conta, e faz dela mais caso que das outras. Isto tem por Estado e por honra" (GÂNDAVO, 1980, p. 13).

7 “Não adoram cousa alguma nem têm pela si que há na outra vida glória pelos bons, e pena pela os maus, tudo cuidam que se acaba nesta e que as almas perecem com os corpos, e assim vivem bestialmente sem ter conta, nem peso, nem medida" (GÂNDAVO, 1980, p. 13).

"Eles trouxeram todos os ídolos existentes na cabana, sentaram-se à minha volta e contaram que os ídolos haviam profetizado que eles iriam capturar um português. Ao que respondi: "Essas coisas não têm poder. Também não podem predizer nada, elas mentem que eu seja português" (STADEN, 1974, p. 58).
} 
por meio da negação do ameríndio enquanto sujeito pensante e produtor de conhecimento. "Uma vez reconhecidos os territórios, geograficamente, passavam-se ao controle dos corpos, das pessoas: era necessário "pacificá-las" - dizia-se na época" (DUSSEL, 1993, p. 43).

A obra As singularidades da França Antarctica ${ }^{8}$, publicada originalmente em 1557, em Paris, pelo Frei franciscano André Thevet ${ }^{9}$, foi resultado de uma viagem ao território recém-nomeado Brasil, no período de novembro de 1555 a janeiro de 1556. A obra apresenta 41 xilogravuras e relata observações de Thevet sobre a natureza e um grupo de indígenas da Baía de Guanabara sobre os quais afirma serem:

Estranhíssimos povos selvagens, sem fé, lei, ou religião e nem civilização alguma, vivendo antes como animais irracionais, assim como os fez a natureza, alimentando-se de raízes, andando sempre nus tanto os homens quanto as mulheres, à espera do dia em que o contato com os cristãos lhes extirpe esta brutalidade, para que eles passem a vestir-se, adotando um procedimento civilizado e humano. (THEVET, 1978, p. 98)

Ainda em 1557, na Alemanha, foi publicada a obra Duas viagens ao Brasil ${ }^{10}$, de Hans Staden, o qual esteve no Brasil para lutar contra os franceses e indígenas e, por conta disso, é tomado como prisioneiro de guerra pelo grupo Tupinambás. A referida obra popularizou-se em toda a Europa devido à descrição de Staden sobre a prática da antropofagia, quando o autor relata com detalhes como quase foi devorado e também sua fuga. Sobre a antropofagia, Staden (1974, p. 176) afirmou que os nativos "fazem isto,

8 Do original: Les singularitez de la France Antarctique de 1557. Nesta obra utiliza-se a versão brasileira de 1978.

9 Thevet figura entre os cronistas do descobrimento também com a obra La cosmographie universelle d'André Thever, cosmographe de Roy (1575 e sem tradução ao português), na qual dedica um dos quatro tomos exclusivamente a descrição dos tupinambás.

${ }^{10}$ Do original: Warhaftige Historia und beschreibung eyner Landtschafft der Wilden Nacketen, Grimmigen Menschfresser-Leuthen in der Newenwelt America gelegen de 1557. Nesta obra se utiliza a versão brasileira de 1974.

A título de curiosidade a primeira tradução da obra foi realizada em 1925 por Monteiro Lobato, como: Meu Cativeiro Entre os Selvagens do Brasil, em 1927 o autor lançou uma versão da história para crianças intitulada As Aventuras de Hans Staden, na qual o mercenário alemão é apresentado como um herói que derrota os nativos. 
não para matar a fome, mas por hostilidade, por grande ódio". Tal declaração compôs fertilmente o imaginário sobre o país por muitos anos.

A obra Viagem à Terra do Brasil'11, publicada em 1578, na Suíça, é um diário de bordo produzido pelo missionário protestante Jean Léry, anos antes. A publicação se deu em oposição à obra de Thevet, que deliberadamente exagerou em seus relatos da paisagem e dos nativos, mas que principalmente criticou a ação dos protestantes no Brasil. Nos interessa da obra, no entanto, o tema da antropofagia tomado novamente sob a ótica da demonização dos nativos.

Mas não comem a carne, como poderíamos pensar, por simples gulodice [...] seu principal intuito é causar temor aos vivos. Move-os a vingança [...] para satisfazer seu sentimento de ódio, devoram tudo do prisioneiro, desde os dedos dos pés até o nariz e cabeça, com exceção dos miolos, em que não tocam. (LÉRY, 1980, p. 180)

Em sua ótica de clérigo, a cultura indígena foi tomada por ausência.

Não têm nenhum ritual nem lugar determinado de reunião para a prática de serviços religiosos, nem oram em público ou nem particular. Ignorantes da criação do mundo não distinguem os dias por nomes específicos, nem contam semanas, meses e anos, apenas calculando ou assinalando o tempo por lunações. Não só desconhecem a escrita sagrada ou profana, mas animada, o que é pior, ignoram quaisquer caracteres capazes de distinguirem o que quer que seja. (LÉRY, 1980, p. 205-206)

A obra Tratado da Terra do Brasil'12, de 1576, do cronista português Pero de Magalhães Gândavo, tinha por intenção propagandear a terra e suas riquezas em potencial aos portugueses pobres a fim de convencê-los a migrarem ao território do Brasil. Talvez a descrição dos nativos não tenha contribuído a esse fim, pois, segundo ele (1980, p. 25), "Sam desagradecidos em gran maneira, e mui deshumanos e cruéis, inclinados a pelejar, e vingativos por extremo. Vivem todos mui descançados sem terem

\footnotetext{
${ }^{11}$ Do original: Histoire d'un voyage faict en la terre du Brésil de 1578. Nesta obra se utiliza a versão brasileira de 1980.

${ }^{12}$ Nesta obra, utiliza-se a versão brasileira de 1980.
} 
outros pensamentos senam de comer, beber, e matar gente”. Sobre os Aymorés, em específico, habitantes das matas da região do Espírito Santo, Gândavo alerta a seus leitores que:

\begin{abstract}
Vivem entre os matos como brutos animais; são mui forçosos em extremo, trazem uns arcos mui compridos e grossos conforme a suas forças e as flechas da mesma maneira. Estes indios têm feito muito dano aos moradores depois que vieram a esta Costa e mortos alguns portugueses e escravos, porque são inimigos de toda gente. Não pelejam em campo nem têm ânimo para isso, põem-se entre o mato junto de algum caminho e tanto que passa alguém atiram-lhe ao coração ou a parte onde o matem e não dispensam flechas que não na empreguem. Finalmente, que não têm rosto direito a ninguém, senão a traição fazem a sua. As mulheres trazem uns pães tostados com que pelejam. Estes indios não vivem senão pela flecha, seu mantimento e caça, bichos e carne humana. (GÂNDAVO, 1980, p. 08)
\end{abstract}

Se, por um lado, as obras desse estilo permitem conhecer, em alguma medida os hábitos nativos e seus modos de vida, sendo essas as fontes disponíveis, por outro, o pensamento do europeu sobre o Novo Mundo está contaminado por suas próprias experiências com a guerra e com o enfrentamento ao outro. Nota-se que todas as obras se utilizam de alguns elementos muito recorrentes na literatura da época, como a crueldade em batalha, a antropofagia, a poligamia e as armas - arco e flecha. Tais elementos foram deslocados das narrativas dos cruzados; eram temores relacionados aos árabes mouros que foram trazidos com destaque nas descrições do Novo Mundo, dando indícios de que, independentemente da religião ou nacionalidade dos escritores, visto termos um frei católico, um protestante e mesmo um mercenário sem declarada religiosidade operando com um mesmo discurso. Thevet (1978, p. 89) chega a declarar essa comparação em sua obra: "os antigos turcos, mouros e árabes praticavam desta maneira [...] também usavam eles das semelhantes armas de nossos selvagens". 


\section{O mito da modernidade e o encobrimento da multiplicidade}

Esta necessidade de tornar o nativo americano um ser desprovido de humanidade está estreitamente relacionada à criação do conceito de Modernidade, conforme defende Enrique Dussel, em sua obra, 1492: A origem do mito da modernidade: o encobrimento do outro (1993), na qual o autor sintetiza o processo de constituição do ego europeu. Ego este que se constituiu da experiência de se instituir como centro de referência a partir do qual se fundamenta a dualidade eu - outro, centro - periferia, completude - falta.

A modernidade originou-se nas cidades européias medievais, livre, centros de enorme criatividade. Mas "nasceu" quando a Europa pôde se confrontar com o seu "Outro" e controlá-lo, vencê-lo, violentá-lo: quando pôde se definir como um "ego" descobridor, conquistador, colonizador de Alteridade constitutiva da própria Modernidade. De qualquer maneira, esse "Outro" não foi "descoberto" como "Outro", mas foi "en-coberto" como o "si-mesmo" que a Europa já era desde sempre. (DUSSEL, 1993, p. 08 , grifos do autor)

O eurocentrismo ou falácia desenvolvimentista designa o pensamento gerado pelo ego europeu ao encontrar-se com o outro, mas sem reconhecê-lo como capaz em sua diferença, e, sim, como um ser diferente de si, por isso ainda incompleto, imaturo, inferior, cuja imaturidade de sua consciência requer um direcionamento para que atinja o mesmo patamar de "desenvolvimento" que o europeu. Assim, o ego europeu reorganiza o mundo ao seu redor a partir de uma hierárquica escala de desenvolvimento cultural, intelectual e tecnológico e para a qual elege a si próprio como parâmetro e destino. Daí provém o "mito" da Modernidade, pois parece lógico que, estando já no patamar mais elevado, em seu próprio entendimento, de desenvolvimento da humanidade, que ele - o europeu - estaria também cronologicamente em um outro período-lugar, a Modernidade, enquanto os outros povos e culturas estavam, ainda, em uma pré-história do desenvolvimentismo.

A “conquista" é um processo militar, prático, violento que inclui dialeticamente o Outro como o si-mesmo. O Outro, em sua distinção, é 
negado como Outro e é sujeitado, subsumido, alienado a se incorporar à Totalidade dominadora como coisa, instrumento, como oprimido, como "encomendado", como "assalariado" (nas futuras fazendas), ou como africano escravo (nos engenhos de açúcar ou outros produtos tropicais). (DUSSEL, 1993, p. 44, grifos do autor)

Nesse sentido, a colonização da América “não é um ‘descobrimento’ do novo, mas simplesmente o reconhecimento de uma matéria ou potência onde o europeu começa a ‘inventar’ sua própria imagem e semelhança” (DUSSEL, 1993, p. 35). O eurocentrismo é um movimento de pensamento de tornar a particularidade europeia em universalidade, e, nesse sentido, "nega a América porque a define como matéria, potência, não-ser" (DUSSEL, 1993, p. 35). Esse movimento, então, faz com que não se tenha uma história da América, mas uma história da Europa na América. Aqui, reside um ponto central à constituição deste capítulo, burlar em alguma medida essa lógica que determina que a história do Brasil, que nossa história enquanto brasis se inicia com a chegada dos espanhóis e portugueses.

$\mathrm{Na}$ análise dos processos de colonização, o emprego da violência representou uma das técnicas mais decisivas no estabelecimento de uma nova ordem cultural, política, econômica, educacional, social e religiosa.

Evidentemente que a escravização dos nativos, sua caça e morte em batalhas contra armas de que não dispunham compõem a imagem de violência que se tem no imaginário popular. No entanto, há que se considerar outros processos violentos que cercearam também aos que não foram escravizados, mortos ou confrontados e que resultaram em um massacre grandioso. Dentre estes, destaca-se a criação da categoria índio através da qual se tornam todos um, todos sem nomes, todos iguais.

A criação da categoria índio é uma das violências praticadas aos nativos, pois torna insignificantes as particularidades, as individualidades e apaga a pluralidade cultural. Para Lopes, em sua obra, 1499: O Brasil antes de Cabral (2017), o território "chegou a contar com populações densas, sociedades com hierarquias políticas complexas e multiétnicas, monumentos de respeito, redes de comércio que se estendiam por milhares de quilômetros e tradições artísticas espetaculares" (LOPES, 2017, p. 12-13); no entanto, 
quando da abordagem dessas populações em nossos registros históricos, muito pouco das individualidades de cada grupo, de cada sujeito se manteve após o contato com o europeu. Isso deve-se, de acordo com Maestri, aos colonizadores estarem "inseridos em uma tradição mercantilista e expansionista que fazia tábula rasa das culturas com quem entravam em contato antagônico" (MAESTRI, 1995, p. 11).

Em sua obra Os senhores do litoral: Conquista portuguesa e agonia tupinambá no litoral brasileiro (1995), Mário Maestri afirma que a nomenclatura "índio" surge de um erro de localização, visto que os navegantes europeus pensavam estar desembarcando nas costas extremo-orientais das Índias. "Nasceu, portanto como um substantivo pátrio gerado pelos enganos e ilusões geográficas de Cristóvão Colombo" e "rapidamente, a palavra tornou-se um estereótipo e passou a definir homens tidos como atrasados, ingênuos e preguiçosos. Homens inferiores, enfim" (MAESTRI, 1995, p. 11). Com a denominação "índio", os colonizadores reduziram as diversidades e divergências internas de cada grupo, homogeneizando a todos que não eram europeus: assim, em uma visão simplista, o mundo que se criava estava composto por dois elementos: o branco e o índio.

Para Luís Felipe Baeta Neves, em O combate dos soldados de cristo na terra dos papagaios: colonialismo e repressão cultural (1978, p. 28), a "ideia de universalidade implica outras ideias: integração e unidade". Nesse sentido, o autor defende que, para além de uma categorização inocente que pressupõe todos os habitantes nativos como um só povo, a criação da categoria índio é uma determinação política que retira dos sujeitos o poder sobre si e sua história.

Em princípio, o indígena é visto como um grupo homogêneo, sem diferenças significativas quer quanto à "raça", cultura, origem ou qualquer outro traço distintivo. Portanto, não há "índios" no sentido de uma pluralidade e especificidade culturais ou "raciais" ou históricas. Quando se fala de "índio", o plural é relativo a uma coleção de indivíduos que podem entre si nomear-se de maneira distinta mas que, para o português, é, no essencial, uma mesma e única realidade. O colonizador português - ou, pelo menos o catequista jesuíta - tende, coerentemente, a nominar os locais por um coletivo: gentio [...] a visão do gentio como incontável e indiferenciada coleção de indivíduos não leva a uma percepção de individualidades, de pessoas humana singulares entre os indígenas; e uma coleção de indivíduos sem nomes, sem diferenças: são 
apenas "índios", algarismos mais ou menos próximos e/ou perigosos. Há, então, um movimento duplo em direção à homogeneização: apagam-se as diferenças culturais tribais e as diferenças inter-individuais. (BAÊTA NEVES, 1978, p. 45-46, grifos do autor)

Nesse mesmo sentido, Aníbal Quijano, em sua obra Colonialidade do poder, Eurocentrismo e América Latina afirma que os ibéricos quando da colonização da América:

[...] encontraram um grande número de diferentes povos, cada um com sua própria história, linguagem, descobrimentos e produtos culturais, memória e identidade. São conhecidos os nomes dos mais desenvolvidos e sofisticados deles: astecas, maias, chimus, aimarás, incas, chibchas, etc. Trezentos anos mais tarde todos eles reduziam-se a uma única identidade: índios. Esta nova identidade era racial, colonial e negativa. Assim também sucedeu com os povos trazidos forçadamente da futura África como escravos: achantes, iorubás, zulus, congos, bacongos, etc. No lapso de trezentos anos, todos eles não eram outra coisa além de negros. (QUIJANO, 2014, p. 127)

A identificação de alguns remanescentes desses povos com a designação índio é bastante recente, fruto de uma construção iniciada há 500 anos, cujo ponto central se insere na luta por políticas públicas que garantam sua soberania sobre seus territórios se apropriar das regras (leis) do mundo do branco a fim de garantir a sua sobrevivência. Porém, cada grupo ou povo nativo, a partir de sua cosmovisão particular, possui a sua autodeclaração, a sua língua, a sua identificação. Segundo Neves (1978, p. 45), “os Brasis do litoral nomeavam e individualizavam suas comunidades - tupinambás, tupiniquinscaetés, etc.

A nominação realmente importante para as políticas da catequese não é aquela que pespega nomes próprios (que adjetivação rica: "próprios" adequados, corretos, certos!) às unidades do gentio. É aquela que dá nomes às funções e cargos de "índios" na tribo: chefe e feiticeiro ("pagé"). Estes são os indivíduos relevantes porque, identificados, assinalam os centros de poder a conquistar: o poder político-militar e o poder do saber. Esta nominação é produzida por determinações políticas, assim, como a nominação das "tribos" é "engolida" (com os cuidados que vimos): tamoio, temiminó, aimoré, etc. porque facilita a sua 
distribuição no espaço e permite também uma adjetivação político-militar e religiosa - "inimigos”, "aliados”, “cristãos”. (BAÊTA NEVES, 1978, p. 48, grifos do autor)

O nomear e o individualizar eram tidos pelos europeus como atributos do homem ‘civilizado"”, por isso esse "direito" - o de nomear-se ou ter seu nome reconhecido -, em relação a registros históricos, foi negado aos nativos pelos mesmos motivos pelos quais sua humanidade foi posta à prova quando de sua descrição, e aceitar outras formas de vida, estruturalmente diferentes, poria em cheque sua força nas relações de saber e poder que se estabeleciam.

\section{Há índios no Brasil?}

A criação dessa categoria - o índio - como visto, fez-se necessária ao processo de afirmação da superioridade e da constituição da modernidade aos europeus. Em um outro movimento, desconsiderando a origem e o emprego discriminatório do termo, há que se pensar se as características que se relacionam ao conceito de índio são adequadas para fazer referência a todos os povos nativo-americanos.

Para Carlos Fausto, em Os índios antes do Brasil (2010), os nativos foram "logo caracterizados como gente sem religião, sem justiça, sem Estado - uma ideia que, elaborada pela filosofia política, serviu de base ao imaginário sobre o homem natural e o Estado de natureza" (FAUSTO, 2010, p. 10-11). O que, para o autor, recai em erro, visto que estudos antropológicos e arqueológicos ${ }^{13}$ realizados no século $\mathrm{XX}$ apontam para a existência de grandes cacicados no território brasileiro, os quais possuíam sistemas multiétnicos e multilinguísticos, com centralização política, intensa atividade econômicocomercial e complexos sistemas sociais. "Essas sociedades seriam belicosas e expansionistas, com uma organização social e hierárquica mantida por tributos e por uma economia intensiva, capaz de produzir e estocar alimentos em larga escala" (FAUSTO, 2010, p. 34).

\footnotetext{
13 O autor cita os estudos realizados por Julian Steward (1946 -1949); Betty Meggers e Clifford Evans (1957); Anna Roosevelt (1991); Irving Rouse (1992); Kalervo Oberg (1995) e Marshall Sahlins (1963).
} 
Conforme Maestri, pode-se afirmar que a categoria índio é, de fato, "imprópria para designar-se comunidades domésticas aldeãs - como os Tupinambás - nas quais a horticultura assumia já um caráter dominante” (MAESTRI 1995, p. 11), visto que, para o autor, através dela "tem-se designado acriticamente o homem americano. Ou seja, o caçador-coletor, o horticultor de plantação-enxertia e, até mesmo, o agricultor cerealífero que construiu Tenoxtitlan" (MAESTRI 1995, p. 11).

A classificação 'índio' fazia referência clara a um modo de vida dito primitivo em que nenhum dos pilares das sociedades ditas modernas estava presente: são eles a agricultura, capaz de promover a alimentação de indivíduos que não se ocupem dela, tais como artistas e guerreiros; organização política, social e religiosa (presença do Estado em alguma medida); linguagem estabelecida com escrita, artes e valores e presença de produção artesanal, comércio e urbanização (sociedades não nômades e construtoras). Nesse sentido, pode-se afirmar com clareza que boa parte das culturas que aqui se desenvolviam quando da chegada dos portugueses não poderiam ser incluídas nessa categoria, pois seus grupos ou povos possuíam todos os pilares citados. Para Clastres, seria mais coerente qualificar "antes o proletariado europeu do século XIX, iletrado e subalimentado, que seria conveniente qualificar como arcaico" (CLASTRES, 1979, p. 12).

Conclui-se, assim, que a construção da categoria índio utilizou-se de duas principais frentes estratégicas aos dominadores: a afirmação do direito de nomear - poder sobre as alteridades nativas - vindo de uma cultura cristã que se supunha única e desenvolvida, e a escolha cuidadosa das características que descreveriam a categoria; assim, conforme visto em subcapítulo anterior, escolheu-se entre os costumes aqueles mais favoráveis aos objetivos de domesticar e explorar dos conquistadores para serem relacionados aos nativos, tais como o nomadismo, a antropofagia, a poligamia, a violência na guerra, a relação de igual para igual com os animais: todos relacionados ao conceito de primitivismo, de subdesenvolvimento, de necessidade de intervenção, pois iam de encontro aos preceitos cristãos.

A categoria 'índio' ressalta as práticas caçadoras, guerreiras e nômades dessas comunidades em detrimento das atividades horticultoras. Ela 
termina estabelecendo uma analogia inconsciente entre aqueles atos humanos e as práticas caçadoras, a agressividade e o padrão de deslocamento dos grandes animais predadores. (DUSSEL, 1993, p. 09)

Assim, independentemente das práticas culturais, religiosas ou éticas que cada grupo tinha, ao ser classificado na categoria índio, automaticamente, passava a ser poligâmico, antropófago, nômade, entre outros. Importante enfatizar que as práticas descritas não eram unânimes, ou seja, não compunham um padrão de vida dos nativos, e a generalização produzida sobre a diversidade de culturas aqui é entendida como uma das formas de violência utilizada contra estes, a qual consiste em desconsiderar a individualidade dos sujeitos e dos povos, realizando um julgamento e uma classificação a partir do olhar do europeu.

Interessante observar esse exercício de criação de lugares, pois o mesmo europeu que agiu com violência e agressividade sem medidas contra os nativos americanos e seus modos de vida, emprega um discurso que relaciona o nativo a um modo de vida violento e agressivo. Ou seja, há aí todo um jogo de manter coerente a contradição de seu discurso com sua prática: repousa nisso também o mito da modernidade que supõe, em nível de discurso, um posicionamento de superioridade intelectual, benevolência para com os demais povos e tentativa de resgatá-los de um lugar de inferioridade. Enquanto, em nível de ação, volta-se para o emprego das mais primitivas táticas de repressão, tais como a escravização, a tortura, o estupro, a destruição e o uso de violência sem medida.

A força e violência nunca jamais ouvidas nas demais nações e reinos (se faz aqui), já que são forçadas as mulheres (dos índios) contra sua vontade, e as casadas contra a vontade de seus maridos, as mocinhas e meninas de dez e quinze anos contra a vontade de seus pais e mães, por ordem dos alcaides maiores e ordinários ou carregadores as tiram de suas casas e deixam seus maridos, pais e mães sem nenhum regalo, privando-os do serviço que delas podiam receber e vão forçadas servir em casas alheias de alguns encomendeiros ou de outras pessoas, quatro, cinco ou oito léguas e mais, em estâncias e manufaturas, onde muitas vezes ficam amancebadas com os donos das casas, estâncias ou manufaturas. (DUSSEL, 1993, p. 56) 
Ao se considerar a historiografia nacional, aquela vinculada aos livros didáticos e demais materiais formadores de professores e alunos, não vemos - com frequência e detalhes - registros das singularidades de métodos, crenças, costumes e práticas educativas de cada grupo étnico indígena, e isso se deve, em suma, aos processos de desumanização, categorização e violência abordados. Tais processos compõem o eixo apagamento das alteridades. Concomitantemente, um outro eixo estava em movimento, no qual os processos de ensino/aprendizagem e de formação assumem um papel central: o de colonizar os modos de vida. As práticas instituídas são proibidas ${ }^{14}$ e novas práticas são incentivadas. Segundo Clastres, "a história possui um sentido único, que as sociedades sem poder são a imagem do que já não somos e que a nossa cultura é para elas a imagem do que é necessário ser" (CLASTRES, 1979, p. 16).

A colonização da vida cotidiana do índio, do escravo africano pouco depois, foi o primeiro processo "europeu" de "modernização", de civilização, de "subsumir" (ou alienar) o Outro como "si-mesmo"; mas agora não mais como objeto de uma práxis guerreira, de violência pura como no caso de Cortês contra os exércitos astecas ou de Pizarro contra os incas -, e sim de uma práxis erótica, pedagógica, cultural, política, econômica, quer dizer, do domínio dos corpos pelo machismo sexual, da cultura, de tipos de trabalhos, de instituições criadas por uma burocracia política, etc., dominação do Outro. É o começo da domesticação, estruturação, colonização do "modo" como aquelas pessoas viviam e reproduziam suas vidas. (DUSSEL, 1993, p. 50-51)

A presença dos europeus e de seus símbolos e recursos tecnológicos vai criando novos padrões de comportamento, novos modos de vida, que afetam a possibilidade de continuidade dos modos de vida dos nativos que vão perdendo sua descendência para a cultura vigente, visto que muitas crianças e jovens já não são educados nas antigas formas de cada povo; alterações nas estruturas ocorrem reconfigurando a paisagem

\footnotetext{
14 A proibição aos modos de vida dos nativos se deu - a priori - em relação ao discurso, normas e importação dos modos de vida europeu, o que, na prática cotidiana de cada grupo, não resultou num abandono imediato ou definitivo das práticas culturais, as quais, em sua vasta maioria, compõem a herança ancestral de cada povo e por eles são perpetuadas. Porém é necessário perceber que a expansão de uma organização europeia do país foi, com o tempo, aliciando indivíduos seja por meio da conversão ao catolicismo, seja pela proximidade à urbanização, inclusão escolar, entre outros mecanismos de imersão ao mundo europeu.
} 
religiosa e cultural por meio da inserção de outras simbologias, católicas e urbanas em sua maioria.

Disso resulta uma profunda alteração da paisagem natural e cultural desses povos, pois, se antes em todo o território havia uma forte relação mística com a natureza e seus fenômenos-deuses, mitos e crenças fundantes, com a inserção dos modos de vida europeus vai se constituindo uma nova relação de sacralidade com as cruzes, imagens e construções arquitetônicas que remetem ao culto ao catolicismo. Aos poucos, os deuses antigos vão deixando de significar às gerações posteriores e a fé católica vai ocupando seu lugar na constituição cultural do território. Como também, aos poucos, diminuíram os territórios de floresta e habitats naturais, dando lugar ao crescimento desenfreado de cidades e fazendas. Com isso, diminui-se significativamente os espaços em que os nativos podiam há 500 ano e, ainda hoje, podem preservar seus costumes.

Não que os colonizadores ignorassem totalmente as crenças dos nativos, ao contrário, eram atentos a estas a fim de conhecê-las para identificar sua presença e coibilas. Nas palavras do escritor jesuíta José de Acosta, em 1589, em sua obra Historia natural y moral de las Indias 15: "Não é só útil mas totalmente necessário que os cristãos e mestres da lei de Cristo saibam os erros e superstições dos antigos, para ver se clara e dissimuladamente as usam também agora os índios" (ACOSTA, 1954, p. 139).

Para o europeu,

Todo o "mundo" imaginário do indígena era "demoníaco" e como tal devia ser destruído. Esse mundo do Outro era interpretado como o negativo, pagão, satânico e intrinsecamente perverso. $O$ método da tábula rasa era o resultado coerente, a conclusão de um argumento: como a religião indígena é demoníaca, e a europeia divina, a primeira deve ser totalmente negada e, simplesmente, começar-se de novo e radicalmente a partir da segunda o ensino religioso. (DUSSEL, 1993, p. 61)

\footnotetext{
15 Do original em Latim: De natvra nobi orbis libri dvo, et de promvlgatione evangelii apud barbaros sive de procvranda indorvm salvte (1589). Tradução do trecho utilizado de Henrique Dussel.
} 
Toda essa atenção, no entanto, acabou por preservar de algum modo registros dessas culturas e permite que possamos enxergar nas práticas culturais-religiosas contemporâneas a presença de um sincretismo entre ambos os mundos: o nativo e o estrangeiro. Disso parte a crença de que se pode nomear o processo de colonização e inferiorização do mundo nativo como um encontro entre culturas, no entanto, cabe pensar se pôde haver diálogo - oportunidade de fala a ambos - quando o saber do nativo é tido como "erro" e "superstição".

Ainda na obra supracitada, Acosta realiza uma divisão dos povos nativos dos demais continentes a partir da visão do desenvolvimento de tais povos. O termo "bárbaros" era empregado para designar os nativos americanos. Segundo o autor, estes eram "os que rejeitam a reta razão e o modo comum dos homens" (ACOSTA, 1954, p. 392) e, havia três categorias de bárbaros. Na terceira, habitava a vasta maioria dos nativos do território sul-americano: não pertencentes a culturas urbanas e com escrita desenvolvida.

Nela entram os selvagens semelhantes às feras... e no Novo Mundo há deles infinitas manadas... se diferenciam pouco dos animais ... A todos estes que mal são homens, ou são homens pela metade, convém ensinar a aprenderem a ser homens e instruí-los como a crianças... é preciso contê-los com a força ... e mesmo contra a sua vontade, de certo modo, forçá-los (Lucas 14, 23) para que entrem no reino do céu. (ACOSTA, 1954, p. 392, tradução de Henrique Dussel)

Nesse sentido, Dussel (1993) e Arciniegas (1990) questionam a teoria do “encontro" entre culturas, pois, para eles, essa é antes de uma defesa de uma cultura mestiça, o encobrimento da devastação causada ao mundo do outro pelo europeu. Ou seja, é a criação de um novo mito, "o do Novo Mundo como uma cultura construída a partir da harmoniosa unidade de dois mundos" (DUSSEL, 1993, p. 64). Em que o método da "tábula rasa" agiu de maneira a apagar tudo o que o europeu não entendia como cultura, pois desprezava toda a relação de crenças, mitos e divindades dos nativos. 
Ainda assim, em geral, reconhece-se a existência do sincretismo e da sobrevivência de elementos culturais nativos com a manutenção de práticas ritualísticas e de espaços sagrados como uma força que a Igreja Católica não pôde apagar e que sobreviveu nas "periferias" desse novo mundo. Tal fato demonstra tanto a resistência como a resiliência desses povos, na busca pela manutenção dos seus modos de vida, mesmo que aquém da centralidade cultural colonizadora, nas relações cotidianas do povo: "É evidente que, no claro-escuro das práticas cotidianas, iniciava-se uma religião sincrética, que a mais pura Inquisição (quando houve) não pôde evitar; mas esta não foi a intenção dos missionários, nem dos europeus, mas foi o produto da criatividade popular" (DUSSEL, 1993, p. 65). O que o autor vem a nomear de criatividade pode-se pensar como uma forma de resistência nativa, intencional para alguns, a qual se proliferou em um espaço em que as doutrinas cristãs e escolarizantes não tiveram o alcance suficiente, pois as camadas populares ${ }^{16}$ nunca foram o alvo das investidas educacionais "civilizantes" dos jesuítas.

Nossos saberes tradicionais dão conta de trazer respostas às muitas das questões do que a sociedade contemporânea necessita, pois é importante entender que partilhamos dessa sociedade, estamos todos na mesma estrada, ou seja, fazemos parte do mesmo universo e devemos nos preocupar com ele. Ainda assim, é cabível lembrar que a própria Ciência (europeia) se utilizou da ciência indígena como base de suas pesquisas, entretanto, destituindo os saberes das questões que são inerentes à cultura e espiritualidade que nos é peculiar. (PERALTA, 2017, p. 09-10)

Conforme nos aponta Peralta (2017), escritor e indígena ${ }^{17}$ da etnia Kaiowá, a construção dos saberes europeus se utilizou dos saberes nativos, porém, separando-os das questões culturais e próprias da produção do conhecimento dos nativos, configurando-se em uma apropriação/ expropriação desses saberes. A questão maior está na hegemonia do saber; ao analisar os registros quinhentistas, percebe-se que apenas os conhecimentos eurocentrados são tidos como importantes, mesmo que estes saberes

\footnotetext{
${ }^{16}$ Esta relação é abordada com maior ênfase na obra: FELTRIN, Tascieli. Educação popular no Brasil: forças que concorreram para a emergência da Escola Nacional. 2017. Dissertação (Mestrado em Educação) Programa de Pós-Graduação em Educação, Universidade Federal de Santa Maria, Santa Maria, 2017.

${ }^{17}$ Conforme sua própria autodeclaração.
} 
tenham sido apropriados de outros povos. A resistência e a resiliência dos nativos não está, ali, registrada, como também não está nas grandes obras da história do Brasil. Sendo assim, há uma tendência a não vermos esses povos na construção do país, apenas o europeu.

Mayrawë Kayabi define com muita clareza o impacto da colonização da América na cosmopolítica ameríndia; nas palavras dele, “em vez de antes de Cristo e depois de Cristo, para nós [nativos] deveria ser a.B. e d.B., antes e depois do Branco" (MAYRAWË KAYABI, apud LIMA ${ }^{18}$, 2011, p. 01). Assim, o surgimento do europeu na América pôs em operação forças que modificaram essencialmente os rumos de todo o continente e de seus povos. Para entender esse processo, porém, é necessário deslocar a atenção da narrativa histórica oficial, para o lugar de vivência dos nativos, em que tudo o que se tem por verdade desconfigura-se e assume outros significados.

A história efetiva faz ressurgir o acontecimento no que ele pode ter de único e agudo. É preciso entender por acontecimento não uma decisão, um tratado, um reino, ou uma batalha, mas uma relação de forças que se invertem, um poder confiscado, um vocabulário retomado e voltado contra seus utilizadores, uma dominação que se enfraquece, se distende, se envenena e uma outra que faz a sua entrada, mascarada. As forças que se encontram em jogo na história não obedecem nem a uma destinação, nem a uma mecânica, mas ao acaso das lutas. Elas não se manifestam como formas sucessivas de uma intenção primordial; como também não têm o aspecto de um resultado. Elas aparecem sempre na álea singular do acontecimento. (FOUCAULT, 1996, p. 28)

Foucault em Nietzsche, a genealogia e a história (1996) considera a história um campo de saber perspectivo, no qual se assume um posicionamento político e reveste-se este com os pressupostos da razão, objetividade e verdade. A narrativa de um certo fato nunca é imparcial de participação de quem a narra e das forças que a constituíram narrativa histórica. Os acontecimentos da história não são determinados a não ser por forças em confronto e sua inscrição histórica obedece à mesma lógica. Foucault (1996) enfatiza a necessidade de se olhar para o acontecimento em sua singularidade, em sua

18 Lima (2011) não apresenta as referências de ano e página para a citação de Mayrawë Kayabi. 
fabricação, não como sequência lógica, resultado determinado que dá sequência e coerência ao estabelecido.

\section{O mito do encontro entre raças}

Para o antropólogo brasileiro Darcy Ribeiro, em sua obra O Povo Brasileiro a Formação e o Sentido do Brasil (1995), as estratégias postas em movimento pelos colonizadores não permitiram que nossa diversidade étnica se desenvolvesse em uma sociedade multiétnica, na qual cada povo conserva seus costumes e crenças; em sentido oposto, todos foram impelidos a uma identificação com o tipo brasileiro. "Apesar de sobreviverem na fisionomia somática e no espírito dos brasileiros os signos de sua múltipla ancestralidade, não se diferenciaram em antagônicas minorias raciais, culturais ou regionais, vinculadas a lealdades étnicas próprias e disputantes de autonomia frente à nação" (RIBEIRO, 1995, p. 20). O brasileiro, em sua unidade, possui muitas formas, cores e sentidos de ser brasileiro. A cultura se entrelaçou em uma só experiência estética, multi, porém sem história, sem raízes, sem ancestralidade.

Essa unidade étnica básica não significa, porém, nenhuma uniformidade, mesmo porque atuaram sobre ela três forças diversificadoras. A ecológica, fazendo surgir paisagens humanas distintas onde as condições de meio ambiente obrigaram a adaptações regionais. A econômica, criando formas diferenciadas de produção, que conduziram a especializações funcionais e aos seus correspondentes gêneros de vida. $\mathrm{E}$, por último, a imigração, que introduziu, nesse magma, novos contingentes humanos, principalmente europeus, árabes e japoneses. Mas já o encontrando formado e capaz de absorvê-los e abrasileirá-los, apenas estrangeirou alguns brasileiros ao gerar diferenciações nas áreas ou nos estratos sociais onde os imigrantes mais se concentraram. (RIBEIRO, 1995, p. 20)

Importante também pensar na ação colonizante do europeu sobre os povos africanos trazidos ao continente americano a partir de 1550. Antônio Vieira ${ }^{19}$ defendia a tese de que, ao serem expatriados da África, estes se emancipavam da escravidão, pois,

\footnotetext{
${ }^{19}$ Sobre, ver: AZEVEDO, João Lúcio de. História de Antônio Vieira: tomos 1 e 2. São Paulo: Alameda, 2008.
} 
para ele, lá estavam submissos aos de seu próprio sangue, enquanto que, na América, poderiam conquistar a liberdade. Em sua cosmovisão católica, justificava o tratamento recebido de seus senhores como uma forma de expurgar os pecados cometidos anteriormente e conquistar um lugar no céu. "Vieira ensinava que os africanos na África iam para o inferno por causa de seu paganismo e cultos satânicos; no Brasil eram escravos, como um purgatório, para depois da morte conseguir o céu” (DUSSEL, 1993, p. 68).

Neste caso, a justificativa da escravidão pela Companhia de Jesus tinha seus fundamentos histórico-filosóficos embasados nos autores clássicos que engendraram a concepção cristã de mundo. Inicialmente, remete a São Paulo que, ao escrever a Primeira Epístola aos Coríntios, afirmou:

Permaneça cada um na condição em que se encontrava quando foi chamado. Eras escravo quando foste chamado? Não te preocupes com isto. Ao contrário, ainda que te pudesses tornar livre, procura antes tirar proveito da tua condição de escravo. Pois aquele que era escravo quando chamado pelo Senhor, é um liberto do Senhor. (BIBLIA, 1994, p. 2214)

Mas também encontraram amparo em autores mais contemporâneos como Santo Agostinho, o mais importante mentor intelectual da escola patrística (séc. IV), o qual defendia ser uma "guerra justa" aquela motivada pela conversão à fé cristã, e São Tomás de Aquino, que, através da Suma Teológica, defendeu a crença propagada por Aristóteles na escravidão como prática natural entre os homens, em que alguns seriam naturalmente escravos.

\section{Mergulho, submersão e emersão: palavras finais}

Um mergulho nas estratégias, registros e pensamentos europeus - a época da colonização - fez-se necessário à compreensão de fenômenos, mitos e técnicas empregadas na ação colonialista, cujo encadeamento e coesão das ações resultou nas 
atuais condições de existência, autonomia e manifestação das populações nativoamericanas.

Permeadas por ambiguidades internas e limitações às alteridades, a lógica da construção do ego europeu tornou submersos uma série de processos, técnicas educacionais e de transmissão de tradições inerentes aos outros - os não europeus. Ao mesmo tempo em que conhecer tais estratégias permite, em alguma medida, burlar o investimento em aculturação e apagamento das memórias/tradições e fazer emergir indícios das alteridades nativas.

Não há como suprimir os efeitos desastrosos dos processos de colonização e produção de verdade sobre os nativos, visto suas bases estarem fincadas em recursos complexos e profundamente enraizados em nossa sociedade. A compreensão desses saberes, no entanto, está condicionada à compreensão dos povos nativos em sua própria cosmovisão. Como também na dissolução de mitos que legitimam uma série de violências estruturais em operação/manutenção há 500 anos, toda uma cadeia de produção de verdades ditadas pela colonialidade a partir de uma narrativa de merecimento e criação de lugares. A tradição histórica racionalista aponta para a ocupação do território geográfico como acontecimento determinante do enfraquecimento das comunidades nativas e seus modos de vida em relação aos europeus. Uma atenção às forças em operação, por outro lado, destaca que a ocupação geográfica do território nativo só se deu acompanhada por uma ocupação violenta de seu entendimento político, o qual era até então organizado pela pulverização do poder e, do saber; pelo respeito à liberdade e pela dissolução de hierarquias. O modo de ser/agir europeu não figurava dentre os modos de ser/agir conhecidos pelos nativos, daí sua dificuldade de enfrentá-los.

A circulação desses saberes estrangeiros - inúteis na cosmovisão dos povos nativos - se estabelece pelo processo de agenciamento e oferta de garantias educacionais. É a divisão da vida, a criação de espaços próprios ao saber junto com a criação de postos de trabalho que mantêm homens e mulheres, antes parte de um mesmo todo, separados, ocupados por 12, 14 horas que desmantelam a possibilidade de se conciliar os modos de vida anteriores à colonização com os rumos que o país tomou após. 
Enquanto acontecimento singular, o processo de colonização criou fraturas que desestabilizaram as condições de existência tanto físicas, quanto culturais dos povos nativos. Promovendo a desterritorialização de seus saberes e a reterritorialização em uma perspectiva eurocentrada. O que, se considerarmos a história como um acaso das lutas não significa determinantemente a extinção desses saberes, fato este, mais do que comprovado pela resiliência de milhares de nativos que mantêm seus territórios tradicionais, seus modos de vida e produção sustentáveis, suas línguas, crenças e se mantêm, acima de tudo, na centralidade de suas próprias narrativas.

Nas palavras de Clastres (2004, p. 157) "Ao perder a liberdade, o homem perde sua humanidade. Ser humano é ser livre, o homem é um ser-para-a-liberdade. Que mau encontro, portanto, o que pôde levar o homem a renunciar a seu ser e a fazê-lo desejar a perpetuação dessa renúncia". A questão que se coloca quando do aparecimento do europeu no território dos nativos, é que eles não assinaram o contrato, foram coagidos e cooptados por ele. É preciso olhar para a história que nos é repassada, perceber suas fragilidades e violências como um primeiro sinal de reparação, para, a partir desse movimento, reconhecer a diferença, a herança, a resistência, a sabedoria, a singularidade de cada povo. Reconhecer não mais como inferior ou oposta, mas de uma outra natureza com a qual todos somos e devemos aprender a conviver, honrar e a aprender com.

\section{Referências}

ACOSTA, José de. Historia natural y moral de las Indias. Madri: Obras BAE, 1954.

ARCINIEGAS, Gérman. Con América nace la nueva historia. Bogotá: Tercer Mundo Ediciones, 1990.

AZEVEDO, João Lúcio de. História de Antônio Vieira: tomos 1 e 2. São Paulo: Alameda, 2008.

BAETA NEVES, Luís Felipe. O combate dos soldados de Cristo na terra dos papagaios: colonialismo e repressão cultural. Rio de Janeiro: Forense-Universitária, 1978.

BIBLIA. Português. Versão ecumênica. São Paulo: Edições Loyola, 1994. 
CAMINHA, Pero Vaz de. Carta a El-Rei Dom Manuel I. Porto Seguro, 26 de abril a 02 de maio de 1500. [S.I.]: Ministério da Cultura: Fundação Biblioteca Nacional: Departamento Nacional do Livro. Disponível em: http://objdigital.bn.br/Acervo__igital/Livros_eletronicos/carta.pdf. Acesso em: 17 de jun. de 2019.

CLASTRES, Pierre. Sociedade contra o Estado: investigações de antropologia política. Porto: Afrontamento, 1979.

CLASTRES, Pierre. Arqueologia da violência: pesquisas de antropologia política. Brasil: Cosac \& Naify, 2004.

D'ABBEVILLE, Claude. História da missão dos padres capuchinhos na Ilha do Maranhão e terras circunvizinhas. Traduzida e annotada pelo Dr. Cezar Augusto Marques. São Paulo: Livraria Martins Editora, 1945.

DUSSEL, Enrique. 1492: o encobrimento do outro: a origem do mito da modernidade: conferências de Frankfurt. Petrópolis: Vozes, 1993.

DUSSEL, Enrique. Oito ensaios sobre cultura latino-americana e libertação (1965-1991). Tradução de Sandra Trabucco Velenzuela. São paulo: Paulinas, 1997.

FAUSTO, Carlos. Os índios antes do Brasil. Rio de Janeiro: Zahar, 2010.

FELTRIN, Tascieli. Educação popular no Brasil: forças que concorreram para a emergência da Escola Nacional. 2017 Dissertação (Mestrado em Educação) - Programa de PósGraduação em Educação, Universidade Federal de Santa Maria, Santa Maria 2017. Disponível em: https://repositorio.ufsm.br/handle/1/13429. Acesso em: 17 de jun. de 2019.

FOUCAULT, Michel. Nietzsche, a genealogia e história. In: MICROFÍSICA DO PODER. Rio de Janeiro: Edições Graal, 1996. p. 12-23.

GÂNDAVO, Pero de Magalhães. Tratado da terra do Brasil: história da Província Santa Cruz. Belo Horizonte: Itatiaia, 1980.

LÉRY. Jean de. Viagem à terra do Brasil. São Paulo: Editora da Universidade de São Paulo, 1980.

LIMA, Tânia Stolze. Por uma cartografia do poder e da diferença nas cosmopolíticas ameríndias. Revista de Antropologia, São Paulo: USP, v. 54, n. 2, p. 601-646, 2011.

LOPES, Reinaldo José. 1499: a pré-história do Brasil. Rio de janeiro: Harper Collins, 2017. 
MAESTRI, Mário. Os senhores do litoral: Conquista portuguesa e agonia tupinambá no litoral brasileiro. Porto Alegre: Editora da Universidade - UFRGS, 1995.

PERALTA, Anastácio. A agroecologia Kaiowá: tecnologia espiritual e bem viver, uma contribuição dos povos indígenas para a educação. MovimentAção, Dourados, v.4, n. 6, p. 01-19, 2017.

QUIJANO, Aníbal. Colonialidad del poder, eurocentrismo y América Latina. In: CLACSO. Cuestiones y horizontes: de la dependencia histórico-estructural a la colonialidad/descolonialidad del poder. Buenos Aires: CLACSO, 2014. ISBN 978-987-722018-6. Disponível em: http://biblioteca.clacso.edu.ar/clacso/se/20140507042402/eje3-8.pdf. Acesso em: 24 ago. 2020.

RIBEIRO, Darcy. O povo brasileiro a formação e o sentido do Brasil. São Paulo: Companhia das Letras, 1995.

SEGATO, Rita Laura. Gênero e colonialidade: em busca de chaves de leitura e de um vocabulário estratégico descolonial. e-cadernos CES [Online], [Coimbra], n. 18, p. 106-131, dez. 2012. Disponível em: http://journals.openedition.org/eces/1533. Acesso em: 01 out. 2020.

STADEN, Hans. Duas viagens ao Brasil. Belo Horizonte: Itatiaia; São Paulo: Edusp, 1974.

THEVET, André. As singularidades da França Antarctica: a que outros chamam de America. Belo Horizonte: Itatiaia; São Paulo: Edusp, 1978.

Recebido em: 18/10/2020 Aprovado em: 04/04/2021

Universidade do Estado de Santa Catarina - UDESC Centro de Ciências Humanas e da Educação - FAED

PerCursos

Volume 22 - Número 48 - Ano 2021 revistapercursos@gmail.com 